\title{
The trail of the Eagles' Nests - tourist attraction in Bydlin
}

\section{Przystanek na Szlaku Orlich Gniazd - atrakcje turystyczne Bydlina}

\author{
Aleksandra Vierek \\ Faculty of Management Sport and Tourism, \\ The Jerzy Kukuczka Academy of Physical Education in Katowice, \\ 72A Mikołowska St., 40-065 Katowice, Poland \\ E-mail address: a.vierek@awf.katowice.pl
}

\begin{abstract}
The purpose of this paper is an attempt to demonstrate and evaluate natural and cultural values of the small town, which is rarely visited by tourists. Bydlin area is located within both walking and bicycling touristic route "The trail of the Eagles' Nests". The tourist sights and geotouristic values of Bydlin country, was presented. All three selected tourist sites and one geosites have highly cultural, historic and geological values. Described town can be an alternative for well-known and crowded places for tourists from Poland. This is the proposal for a short few hours educational natural and historical trail for tourists with different preferences and predisposition.
\end{abstract}

Keywords: tourist sights; geosite; carbonates; Krakow -Czestochowa Upland; Bydlin

\section{STRESZCZENIE}

Celem artykułu jest próba ukazania i oceny walorów zarówno przyrodniczych, jak i kulturowych niewielkiej miejscowości rzadko odwiedzanej przez turystów. W pracy zaprezentowano atrakcje (geo) turystyczne jakie oferuje wieś Bydlin, przez którą przebiega szlak turystyki pieszej „Szlak Orlich Gniazd” oraz szlak rowerowy o tej samej nazwie. W miejscowości wyznaczono cztery stanowiska turystyczne (w tym jedno geostanowisko), wybrane ze względu na cenne wartości kulturowe, historyczne i geologiczne. Opisywana wieś może stanowić alternatywę dla znanych, tłumnie odwiedzanych przez turystów z całej Polski miejscowości na wspomnianych szlakach. W artykule przedstawiono propozycję krótkiej, kilkugodzinnej ścieżki edukacyjnej przyrodniczokulturowej przeznaczonej dla turystów o różnych preferencjach.

Slowa kluczowe: atrakcje turystyczne; geostanowisko; skały węglanowe; Jura KrakowskoCzęstochowska; Bydlin

\section{WPROWADZENIE}

Teren pomiędzy Krakowem a Częstochową połączony liczącym $163 \mathrm{~km}$ długości Szlakiem Orlich Gniazd to jedno z najpiękniejszych miejsc w Polsce znane miłośnikom 
wędrówek pieszych, rowerowych oraz amatorom wspinaczki skałkowej. Wśród malowniczych wapiennych ostańców blisko tysiąc lat temu powstały tu pierwsze osady ludzkie, a chwilę później wzniesiono warowne, często jeszcze drewniane grody. Za czasów panowania Kazimierza Wielkiego (1333 - 1370) z okolicznego kamienia wapiennego wybudowano wiele zamków obronnych, których ruiny są dziś zarówno ozdobą, jak i atrakcją turystyczną Szlaku Orlich Gniazd. Są wśród nich zamki i warownie tłumnie odwiedzane przez turystów przez cały rok - w Ogrodzieńcu, Ojcowie, Olsztynie, Pieskowej Skale czy w Krakowie. Ale są też miejsca mało poznane, często pomijane w przewodnikach i informatorach turystycznych, a które swą historią i bogactwem przyrodniczym nie ustępują sąsiadom.

Jednym z nich jest Bydlin (Rys.1) - wieś położona około $30 \mathrm{~km}$ na południowy wschód od Ogrodzieńca, nad rzeką Sączenicą (inaczej Tarnówką - dopływem Przemszy).

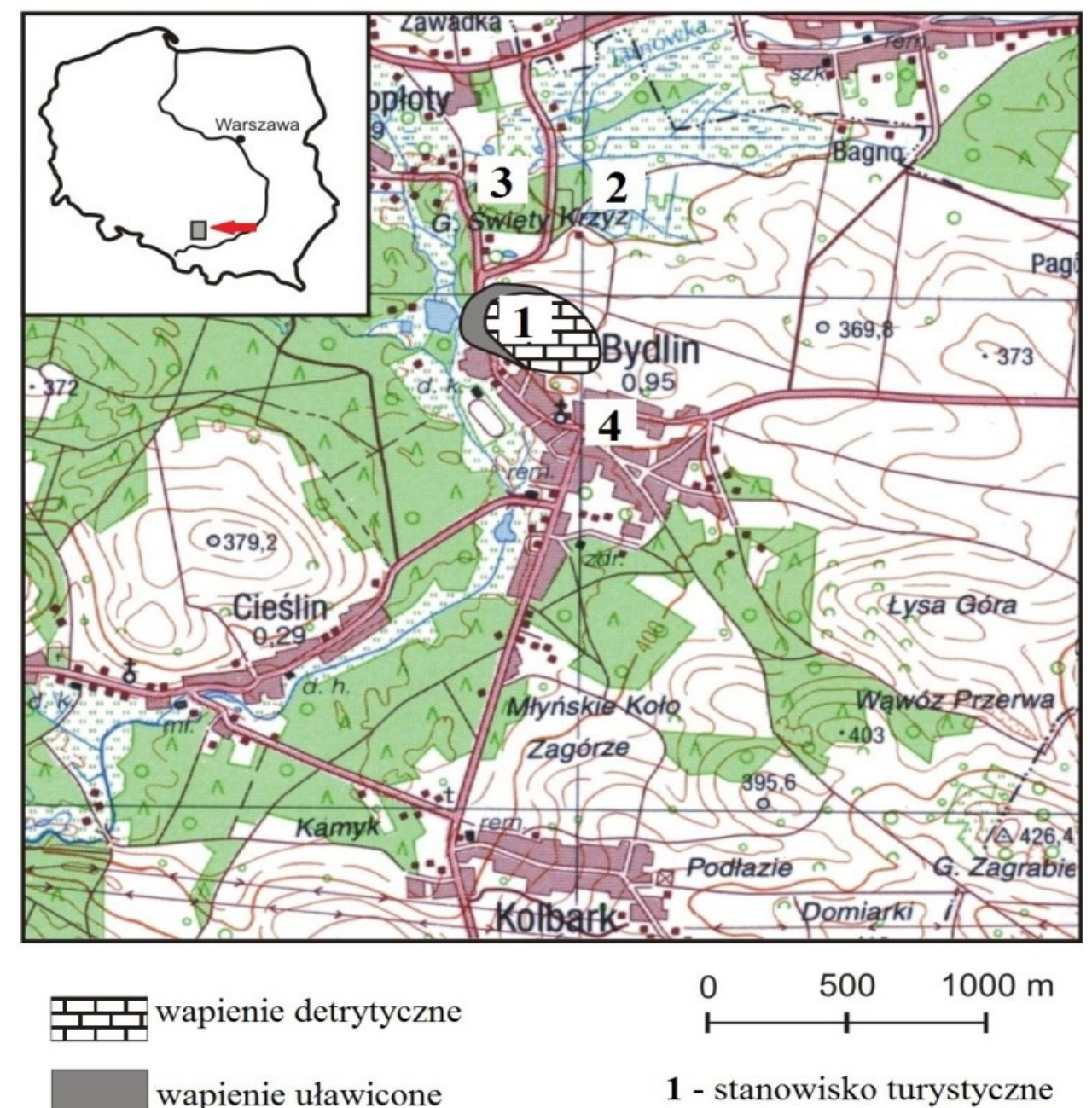

Rys. 1. Mapa topograficzna miejscowości Bydlin i okolic z zaznaczonymi stanowiskami turystycznymi.

Celem artykułu jest próba ukazania rozmaitych walorów zarówno przyrodniczych, jak i kulturowych niewielkiej miejscowości rzadko odwiedzanej przez turystów. Przedstawiono propozycję krótkiej, kilkugodzinnej ścieżki edukacyjnej przyrodniczo-kulturowej 
przeznaczonej dla turystów o różnych preferencjach. Dla większego zrozumienia poruszanych zagadnień geologicznych sporządzono w przystępnej formie słownik trudniejszych terminów, głównie z dziedziny nauk o Ziemi.

\section{HISTORIA BYDLINA}

Wczesna historia Bydlina jest niejasna. Pierwsze wzmianki o wsi pochodzą z 1120 roku (Marzec i in. 1986, s. 127). Przez wieś prowadził wówczas ważny szlak handlowy z Krakowa do Wielkopolski. W XIV wieku miejscowość należała do Niemieży z Bydlina oraz Gałki z Galowa, a następnie przechodziła kolejno w ręce Pełki z Bydlina herbu Strzała oraz Zbigniewa z Łapanowa. Pod koniec XIV wieku prawdopodobnie w 1388 roku Bydlin otrzymał prawa miejskie, które stracił w niewyjaśnionych okolicznościach w roku 1530 (Kiryk i Kołodziejczyk, 1978). Jako miasto stał się własnością mieszczan krakowskich Bonerów, a potem Firlejów. Przez wieki wielokrotnie zmieniał właścicieli. Pod koniec XIX wieku dobra bydlińskie rozparcelowano i oddano w ręce tutejszych włościan. Obecnie miejscowość jest własnością gminy Klucze.

W czasie I wojny światowej Jura Krakowsko-Częstochowska została zajęta przez wojska niemieckie, austriackie i rosyjskie. W okolicy Bydlina i sąsiednich Krzywopłotach w dniach 18-19 listopada 1914 roku polskie oddziały strzeleckie (późniejsze Legiony) stoczyły walki (patrz stanowisko 2). Dla upamiętnienia bitwy wybudowano w okresie międzywojennym (1937 rok) gmach szkoły podstawowej. Obecnie funkcjonuje tu Szkoła Podstawowa oraz Gimnazjum im. Legionistów Józefa Piłsudskiego. Obydwie szkoły do dnia dzisiejszego pielęgnują tradycje patriotyczne, o czym świadczą zgromadzone w Izbie Tradycji liczne pamiątki oraz organizowany od 2002 roku Międzyszkolny Konkurs pieśni Legionowej i Żołnierskiej.

W czasie II wojny światowej w Górach Bydlińskich (przysiółek Bydlina położony około $3 \mathrm{~km}$ na północ od wsi) stacjonowały oddziały partyzanckie Armii Krajowej „Surowiec”. Gęste lasy z licznymi naturalnymi kryjówkami, zagłębieniami terenu, jaskiniami i suchymi dolinami były doskonałym miejscem ukrycia i ochrony „leśnych ludzi”. Stąd dokonywano wielu wypadów i wypraw, w czasie których stoczono liczne potyczki z wojskami niemieckimi (Zinkow, 1983, s. 133).

\section{BUDOWA GEOLOGICZNA OKOLIC}

Obszar, na którym znajduje się Bydlin wchodzi w obręb monokliny śląskokrakowskiej, zbudowanej z różnych ogniw triasu i jury (Żelaźniewicz i in., 2011). Najstarszymi stwierdzonymi utworami w okolicach Bydlina są osady kambru, które zostały nawiercone w otworze P-8 w okolicach Krzywopłotów na głębokości 713-1000 m. Jest to seria piaskowcowo-iłowcowo-mułowcowa $\mathrm{z}$ intruzjami porfirów, powyżej której zalegają osady ordowiku, syluru, dewonu oraz karbonu dolnego, głównie gruboziarniste piaskowce skaleniowo-kwarcowe, mułowce, dolomity, margle oraz wapienie. W odwiertach stwierdzono również obecność utworów permu (zlepieńce wapienno-porfirowe) i triasu (głównie dolomity i zlepieńce). O atrakcyjności geoturystycznej tego obszaru stanowią jednak skały, które ukazują się na powierzchni - jasne, wapienne skały (w nomenklaturze turystycznej - skałki) górnej jury. Ich wychodnie ciągną się szerokim pasem od Krakowa na południowymwschodzie do Wielunia na północnym-zachodzie. 
W tym samym kierunku skałki stopniowo zanikają, ginąc pod coraz bardziej miąższą pokrywą osadów polodowcowych. W literaturze geologicznej obszar występowania wapiennych skał nazywany jest Jurą Polską (Różycki, 1960). Istotne różnice w charakterze sedymentacji górnojurajskiej pozwoliły na wydzielenie tu dwóch rejonów: częstochowskiego i krakowskiego. Bydlin położony jest w południowym, krakowskim obszarze, którego charakterystyczną cechą jest intensywny rozwój budowli węglanowych. W okresie jurajskim cały ten obszar zalany był płytkim morzem o maksymalnej głębokości 150 metrów (Vierek i in., 2011). W ciepłym morzu powstawały różnorodne osady węglanowe. Ich duże zróżnicowanie wynika m.in. z różnej głębokości depozycji materiału węglanowego względem podstawy falowania, cyrkulacji wody morskiej czy charakteru środowiska (np. warunki utleniające). We wczesnym oksfordzie w niegłębokim zbiorniku z ograniczoną cyrkulacją wody osadziły się wapienie margliste (m.in. Vierek i in., 2011). Powyżej (w sensie stratygraficznym) znajdują się wapienie skaliste, z których zbudowana jest większość jurajskich samotnych skał, tzw. ostańców. Są to wapienie bardzo twarde, ale ich wysoka węglanowość - wynosząca do $98 \% \mathrm{CaCO}_{3}$ - powoduje znaczą podatność na procesy krasowienia. $Z$ tego względu tworzą one malownicze skałki najlepiej widoczne w krajobrazie jurajskim. Wapienie skaliste powstały na szelfie, w okolicy podstawy falowania, w morzu dobrze przewietrzanym i w warunkach utleniających.

S. Dżułyński (1952) uznał te wapienie za biohermy tkwiące w obrębie wapieni ławicowych - kolejnego typu litologicznego skał węglanowych. Jasna barwa wapieni ławicowych, drobna frakcja (ziarno) oraz niewielka ilość składników organicznych (= skamieniałości) sugerują miejsce ich powstania w głębszych wodach morskich, spokojnych, poniżej podstawy falowania. W osadach późnego oksfordu zaznaczają się wyraźne zmiany w wykształceniu litologicznym wapieni, które sugerują zarówno niepokój tektoniczny (wstrząsy wywołane uskokami), jak i klimatyczny (sztormy). Tworzą się wapienie o wyraźnie grubszych klastach (ziarnach), tzw. wapienie detrytyczne.

Po wycofaniu się morza jurajskiego obszar jeszcze wielokrotnie był zalewany i opuszczany przez morze okresu kredowego (około 130 - $60 \mathrm{mln}$ lat temu), a następnie po raz ostatni przez morze mioceńskie. Po ostatecznym ustąpieniu morza rozpoczęły się procesy niszczące, związane m.in. $\mathrm{z}$ działaniem lądolodu skandynawskiego oraz procesy geochemiczne polegające na rozpuszczaniu wapiennych skał między innymi przez wody opadowe (= zjawiska krasowe).

\section{WALORY TURYSTYCZNE BYDLINA}

Okolice Bydlina można uznać za atrakcyjne turystycznie, choćby ze względu na obecność dwóch znanych szlaków turystycznych: pieszego (oznaczonego kolorem czerwonym) pod nazwą Szlak Orlich Gniazd i nieco dłuższego $(188 \mathrm{~km})$ rowerowego (oznaczeniem jest sylwetka rowerzysty wpisana w biały kwadrat) nazwanego Jurajskim Szlakiem Rowerowym Orlich Gniazd. Na obu szlakach Bydlin znajduje się pomiędzy Rabsztynem a Smoleniem; od rycerskiego zamku w Smoleniu oddalony jest o około 1,5 godziny marszu.

Podobna odległość dzieli go od warowni w Rabsztynie. Przez Bydlin przebiega również krótsza, proponowana przez A. Stróżeckiego ścieżka rowerowa Smoleń - Bydlin - Ryczów Smoleń o długości 45 km (Stróżecki, 1995, s. 53). Nieopodal Bydlina Szlak Orlich Gniazd krzyżuje się z ważnym czarnym Szlakiem Partyzantów Ziemi Olkuskiej. Przez miejscowość przebiega również Szlak Frontu Wschodniego I wojny światowej. We wsi znajduje się kilka 
atrakcji sakralnych, łatwo dostępne geostanowisko oraz ruiny zamku (opisane poniżej). Zwiedzanie wsi rozpoczynamy od Geostanowiska 1 - można tu zaparkować samochód, a do pozostałych atrakcji dotrzeć przyjemnym spacerem.

\section{1. Geostanowisko 1 - Odsłonięcie skał węglanowych}

W północnej części wsi (Rys. 1) obok szkoły podstawowej im. Józefa Piłsudskiego odsłaniają się wapienie górnej jury (Rys. 2A). Ściany odsłonięcia zawierają bogaty materiał edukacyjny i naukowy $\mathrm{z}$ różnych dziedzin geologii: sedymentologii, paleontologii czy petrografii. Wyróżniono tu dwa typy litologiczne wapieni (Vierek, 1997). Dolną partię budują jasne wapienie o wyraźnym uławiceniu i obecności charakterystycznych białych czertów o wielkości dochodzącej do 10-15 cm. Powyżej zalegają masywne, kremowo-szare wapienie detrytyczne zbudowane $\mathrm{z}$ widocznych klastów (ziaren; Rys. 2B) o różnych wielkościach, od $0,2 \mathrm{~cm}$ do kilkunastu (miejscami nawet kilkudziesięciu) centymetrów, różnym stopniu obtoczenia i upakowania. Różnice w wyglądzie obu typów wapieni są tak wyraźne, że bez problemu powinny być dostrzeżone nawet przez geologa-amatora.

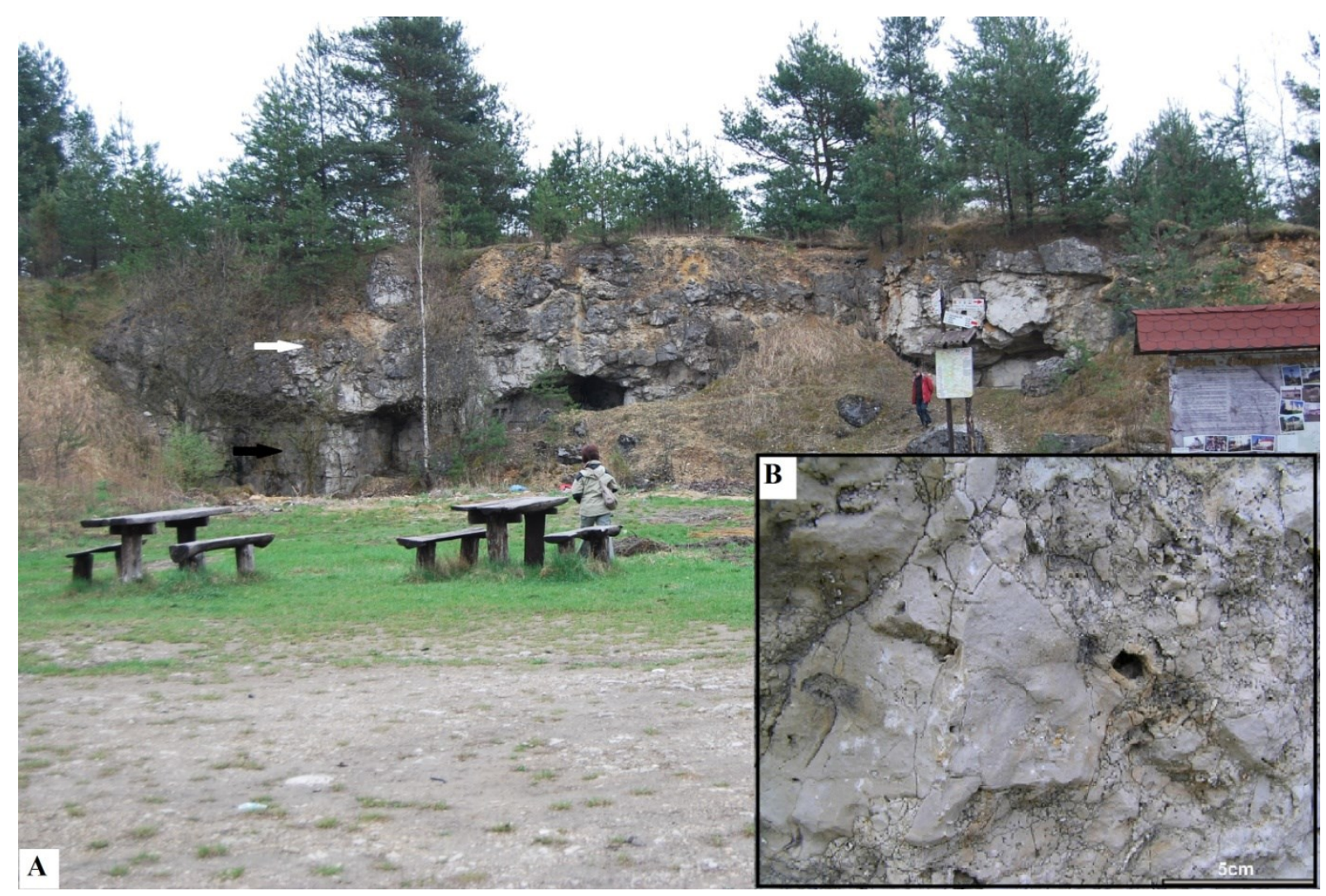

Rys. 2. Widok na północny fragment Geostanowiska 1 (A), strzałką białą zaznaczono wapienie detrytyczne, strzałką czarną wapienie uławicone; w prawym dolnym rogu (B) zdjęcie wapienia detrytycznego - wyraźne klasty o różnej wielkości i różnym stopniu obtoczenia i upakowania (= ułożenia) (fot. A. Vierek, maj 2013).

Bardzo dobrze są tu eksponowane zjawiska z zakresu sedymentologii, zwłaszcza dotyczące charakteru sedymentacji. Dolna część skał odzwierciedla spokojną, normalną sedymentację węglanową zachodzącą w zbiorniku epikontynentalnym, zaś górna część jest świadectwem epizodycznych ruchów masowych oraz przykładem zdarzeń katastroficznych, 
których osady są znane z zaledwie kilku stanowisk na obszarze Jury Polskiej. Także miłośnicy zbierania i kolekcjonowania skamieniałości znajdą tu coś dla siebie. Wapień detrytyczny (górna część profilu) zawiera liczną makrofaunę, wśród której dominują gąbki krzemionkowe (głównie z rodzaju Platychonia) o formach talerzowych dochodzących do 35 cm średnicy. Licznie występują też ramienionogi i belemnity, rzadziej mszywioły.

Przed wyruszeniem w dalszą wędrówkę warto odpocząć - u stóp odsłonięcia przygotowano drewniany stolik i ławeczki dla turystów oraz tablicę informacyjną o wsi i jej atrakcjach (Rys. 2A). Droga na Krzywopłoty jest mało używana, więc ruch samochodów nie zakłuci spokoju, a sąsiedztwo lasu sosnowego zapewni sporą dawkę tlenu.

\section{2. Stanowisko 2 - Wzgórze Świętego Krzyża i cmentarz parafialny}

Kilkaset metrów na północ od Geostanowiska 1 (Rys. 1) dochodzimy do stóp urokliwego, zalesionego wzgórza zamkowego. Pokryte transzejami (wykutymi w litej skale wapiennej) wzgórze i położony u jego stóp cmentarz z oryginalną mogiłą poległych w 1914 roku legionistów są świadectwem stoczonych przez Legiony walk (Stróżecki, 1995 s. 22).

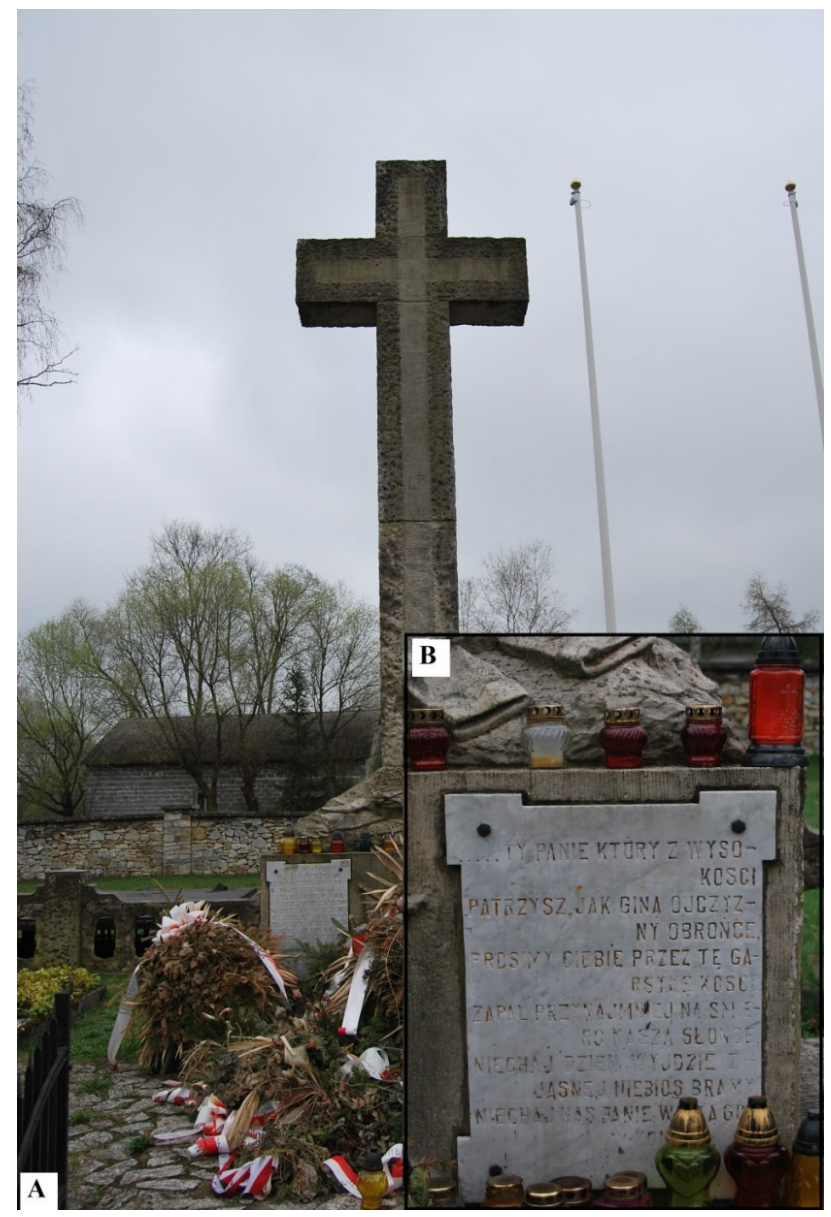

Rys. 3. Krzyż z kamienia ciosowego (A) upamiętniający poległych w boju pod Krzywopłotami; w prawym dolnym rogu (B) marmurowa tablica z wyrytym wierszem (fot. A. Vierek, maj 2013).

$\mathrm{Na}$ wprost wejścia na cmentarz, w centralnym punkcie znajduje się kwatera, w której pochowano poległych legionistów. Wznosi się tutaj kamienny krzyż (ufundowany w 1920 roku; Rys. 3A) o wysokości 7 metrów (Marzec i in., 1986, s. 27), ozdobiony symbolami legionów i marmurowymi tablicami z wyrytym na cześć poległych napisem - fragmentem 
wiersza Juliusza Słowackiego „Pogrzeb Kapitana Meyznera” (Rys. 3B). Wg źródeł w bezpośrednim starciu z wrogiem wzięło udział 440 żołnierzy - zginęło 46 legionistów, a 133 zostało rannych (Zinkow, 1983, s. 131).

$\mathrm{Na}$ cmentarzu warto zatrzymać się również przy zbiorowej mogile żołnierzy polskich poległych w bitwie z wojskami rosyjskimi we wrześniu 1939 roku. Są tu też mogiły żołnierzy rosyjskich i austriackich.

Przy cmentarzu stoi kaplica z XVIII wieku (służyła wówczas jako pustelnia) pod wezwaniem Najświętszej Marii Panny Pocieszenia, rozbudowana w XIX wieku (Rys. 4), a w niej posąg Madonny z Dzieciątkiem z pierwszej połowy XV wieku oraz figury Chrystusa Frasobliwego i posąg św. Jana Nepomucena.

U stóp wzgórza od strony zachodniej tryska źródełko czystej wody. Wg miejscowych podań woda posiada właściwości lecznicze, a tutejsi gospodarze nazywają je „źródełkiem miłości”. W Bydlinie byłam wielokrotnie i zawsze pamiętałam o źródełku - w upalne dni w czasie wędrówki woda doskonale gasi pragnienie.

Od strony południowo-zachodniej na zboczach wzgórza widoczne są zapadliska po szybach eksploatacyjnych kopalni galeny (czynnej w XIX wieku) i niewielkie, porośnięte już hałdy poeksploatacyjne. Od strony wschodniej wyraźnie widać okopy i fortyfikacje polowe wykute w skałach prawdopodobnie przez saperów austriackich (Rys. 5).

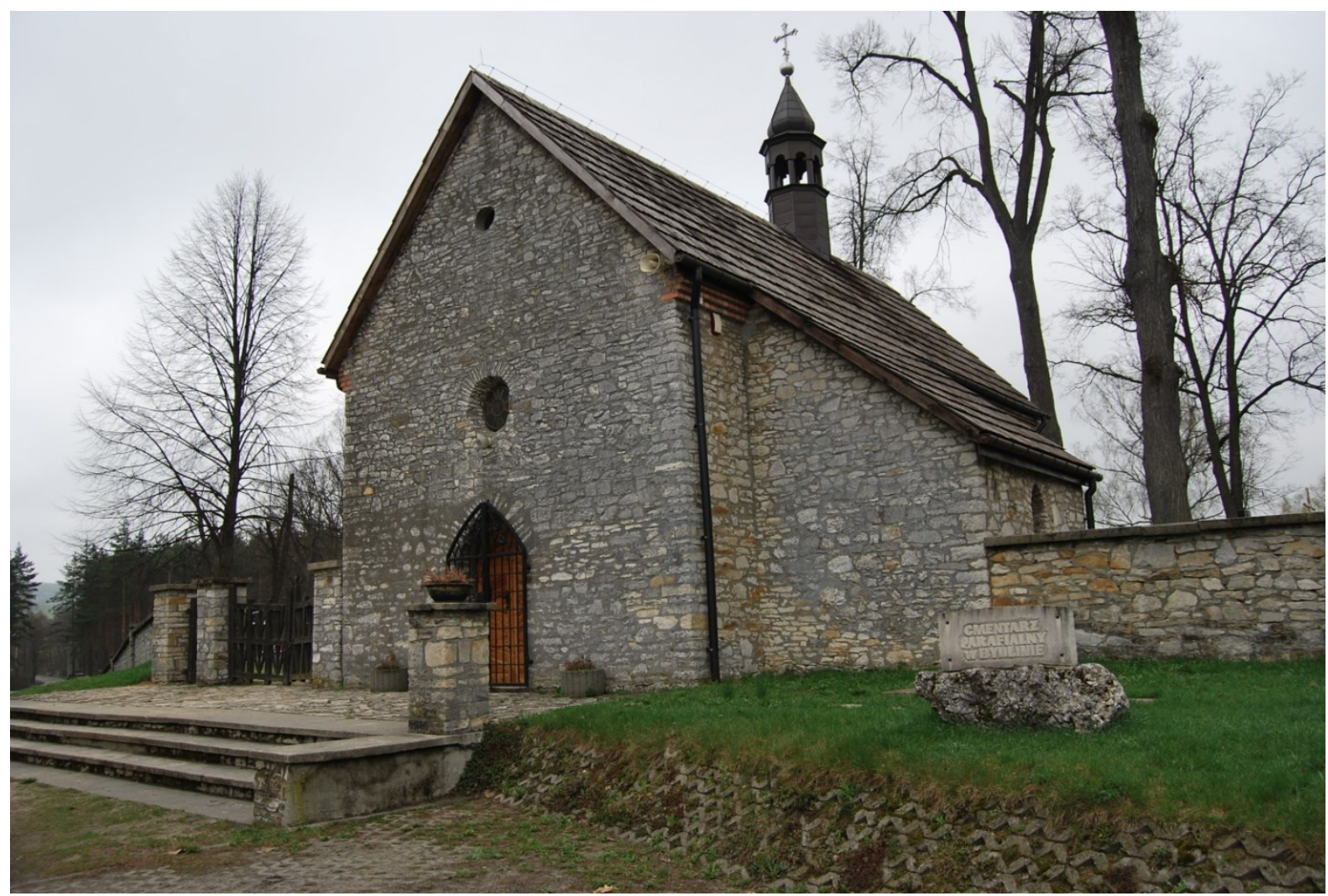

Rys. 4. Murowana kaplica pod wezwaniem Pocieszenia NMP stojąca przy wejściu na cmentarz parafialny (fot. A. Vierek, maj 2013). 


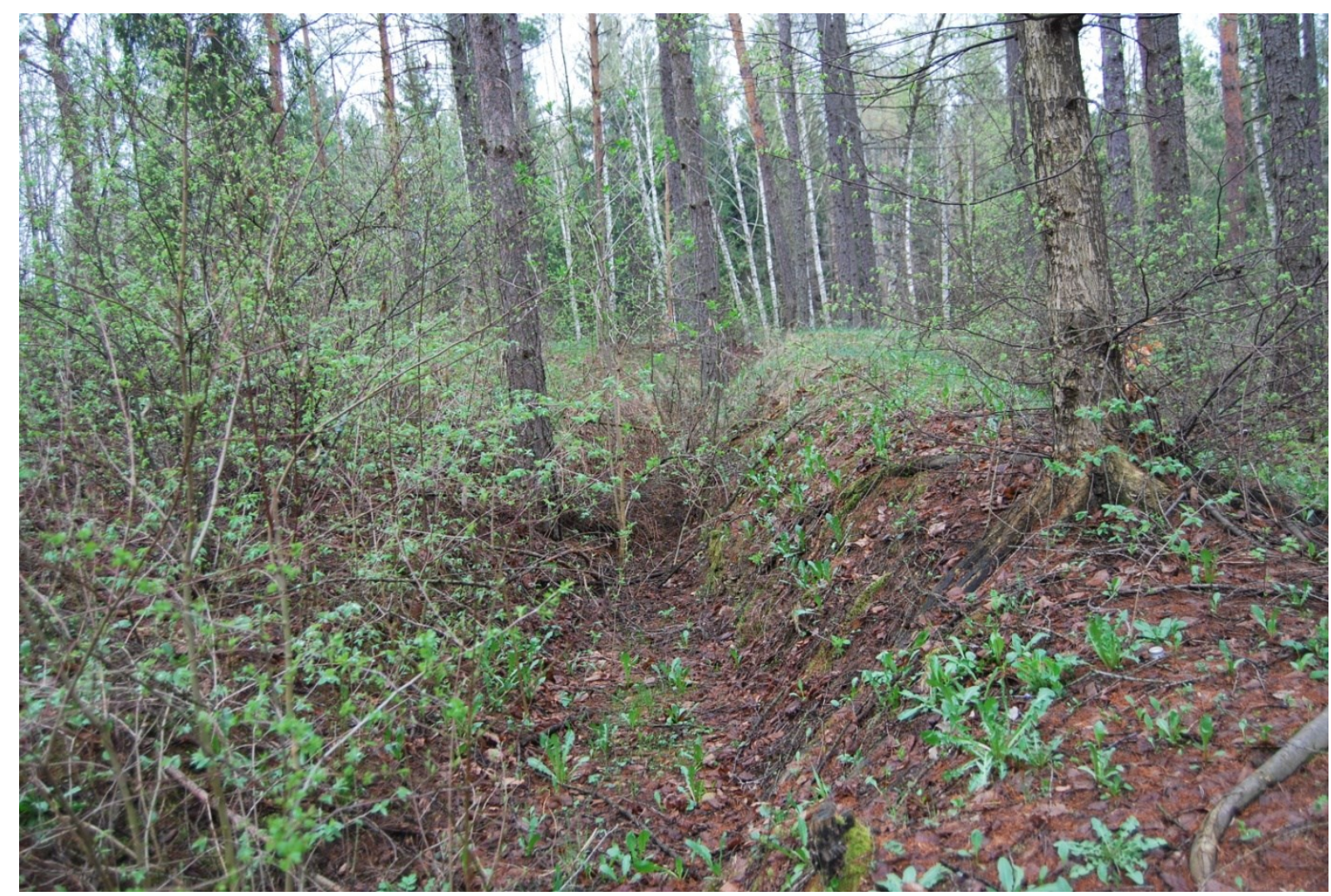

Rys. 5. Zarośnięte obecnie okopy z czasów wojny światowej z 1914 roku (fot. A. Vierek, maj 2013).

\section{3. Stanowisko 3 - Ruiny średniowiecznego zamku}

Na szczycie wzgórza już z daleka można dostrzec postrzępione, białe od wapiennej skały ruiny budowli (Rys. 6). Historia Zamku w Bydlinie jest niejasna. Wyniki badań archeologicznych z 1989 roku prowadzonych pod kierunkiem B. Muzolfa (w: Kajzer i in., 2001) wskazują na obronno-rezydencjonalny (?myśliwski zamek obronny) charakter budowli. Jak wspomniano wcześniej powstał on za panowania Kazimierza Wielkiego - wzniósł go Niemierza herbu Strzała lub jego ojciec Pełka, ale wielokrotnie zmieniał właścicieli. Prawdopodobnie na własność w pierwszym okresie przejął go ród Toporczyków (Zinkow, 1983, s. 40-41). Jedno z odgałęzień tego rodu - Pileccy, w połowie XVI wieku odsprzedali zamek Bonerom (ród starostów niegrodowych).

Pod koniec XVI i w pierwszej połowie XVII wieku przeszedł pod panowanie rodziny Firlejów (spadkobiercy Bonerów). W okresie reformacji, około 1571 roku Jan Firlej przebudował zamek na zbór ariański. Dwadzieścia lat później, w 1594 roku, syn Jana Maciej po odnowieniu przywrócił budowlę kościołowi katolickiemu nadając wezwanie Świętego Krzyża (Zinkow, 1983 s. 130). Mimo, że budowla położona na wzniesieniu była doskonale chroniona przez naturalną wysokość i sztuczne przeszkody od strony podejścia, nie uchroniło jej to od upadku. Koleje losu i liczne napady rabunkowe sprawiły, iż kościół popadł w ruinę. W 1655 roku został spalony i opuszczony (Sypek, 2001).

Zarówno zamek, jak i cmentarna kaplica zbudowane zostały z różnorodnych typów litologicznych wapieni eksploatowanych w okolicy, m.in. wapienia detrytycznego widocznego w Geostanowisku 1. 


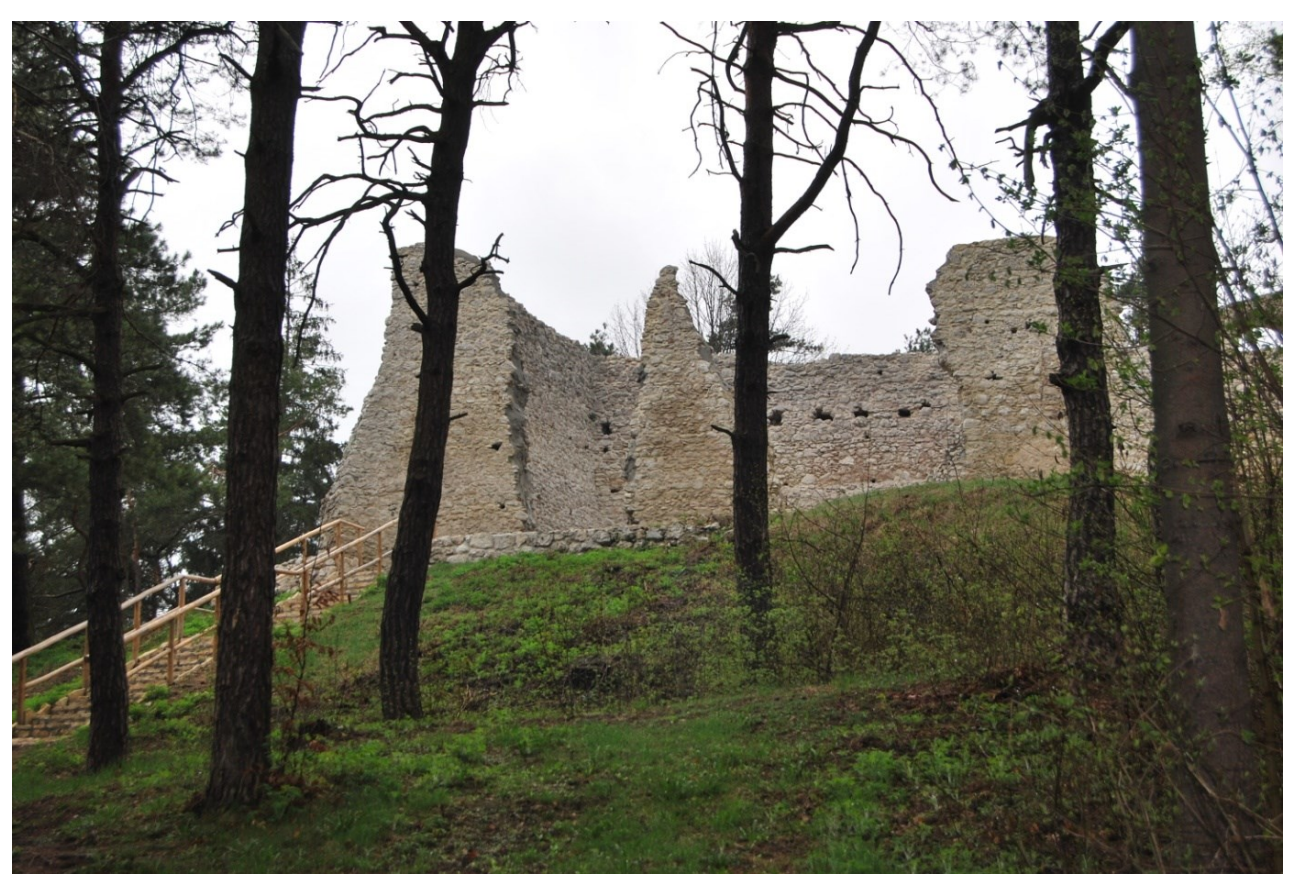

Rys. 6. Ruiny średniowiecznego zamku wyrastające na szczycie lesistego wzgórza. Zwróć uwagę na zadbane, drewniane schody ułatwiające wspinaczkę (fot. A. Vierek, maj 2013).

\section{4. Stanowisko 4 - Kościół parafialny św. Małgorzaty}

W 1747 roku we wsi postawiono drewniany kościółek, który następnie odrestaurowano (wymurowano) i od 1865 roku jest parafialnym kościołem pod wezwaniem Św. Małgorzaty (Rys. 7).

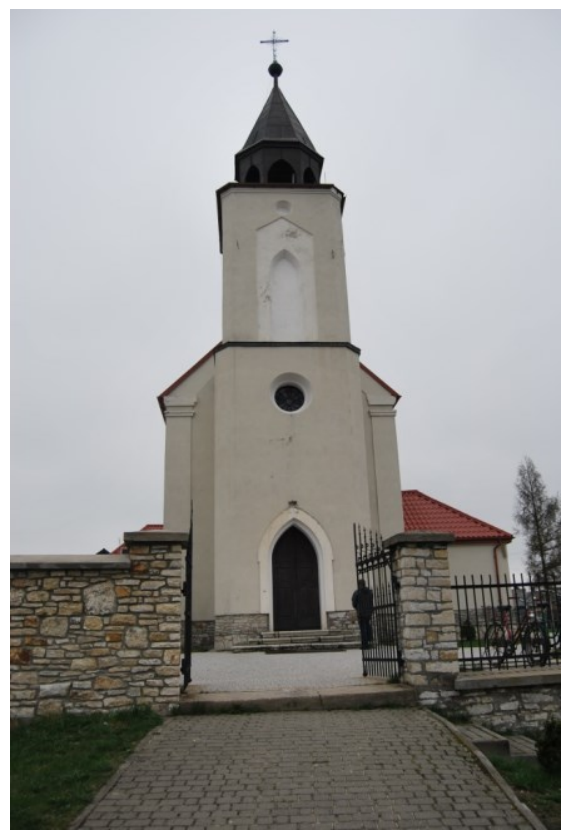

Rys. 7. Kościół parafialny św. Małgorzaty z 1865 roku - widok na główną nawę (fot. A. Vierek, maj 2013). 
Wewnątrz kościoła na uwagę zasługują XVII wieczny posąg Matki Boskiej ustawiony w renesansowym ołtarzu głównym oraz wykonana z czarnego marmuru, chrzcielnica z 1707 roku i monstrancja z XVIII wieku (Marzec i in., 1986, s. 127). Na zewnątrz, przy głównym wejściu stoi figura Najświętszej Boga Rodzicy ufundowana przez Parafian na pamiątkę jubileuszu ogłoszenia Dogmatu Niepokalanego Jej Poczęcia (Rys. 8).

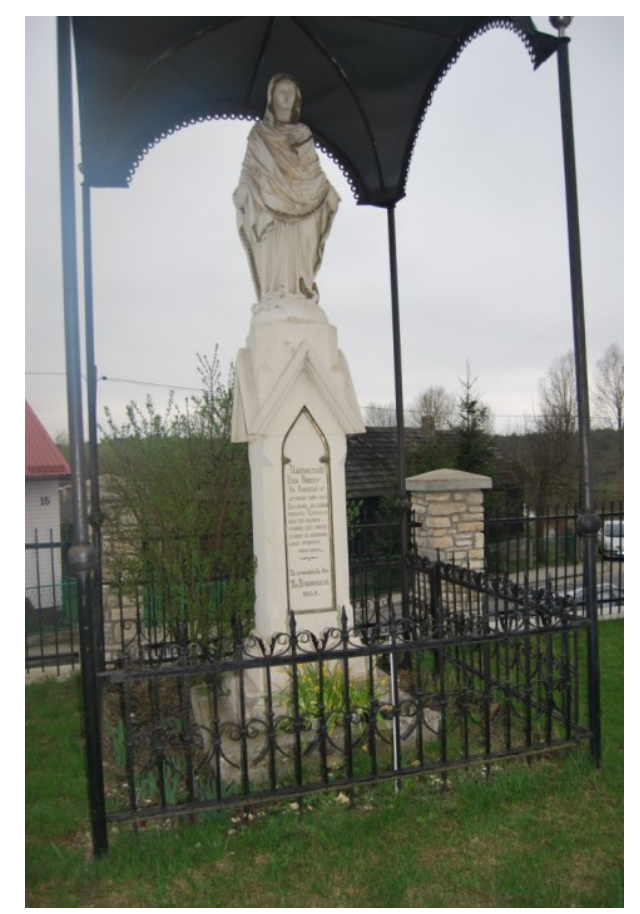

Rys. 8. Figura Najświętszej Boga Rodzicy ufundowana w 1905 roku przez Parafian w dowód czci i wdzięczności za odebrane łaski (fot. A. Vierek, maj 2013).

\section{PODSUMOWANIE}

Miejscowość jest atrakcyjna dla turystów o różnych preferencjach. Można tu uprawiać turystykę pieszą i rowerową jednodniową i weekendową; zatrzymać się na dłużej w gospodarstwie agroturystycznym, by w otoczeniu lasu (bór mieszany sosnowo-bukowy) zregenerować siły. Przebywanie w lesie sosnowym działa łagodząco na układ nerwowy, obniża ciśnienie krwi i wspomaga leczenie dolegliwości układu oddechowego. Domieszka drzew bukowych poprzez dużą zdolność pochłaniania pyłów i metali ciężkich dodatkowo oczyszcza powietrze i thumi hałas. Jak zapewniają też mieszkańcy tutejsze lasy obfitują $\mathrm{w}$ grzyby, jagody i borówki. Taki korzystny mikroklimat boru sosnowo-bukowego, cisza i co ważne, mała ilość turystów zapewni relaks i odpoczynek po tygodniu pracy. Miejscowość położona jest blisko aglomeracji górnośląskiej czy krakowskiej, łatwo i szybko można dojechać tu zarówno samochodem osobowym (ok. $50 \mathrm{~min} \mathrm{z}$ Katowic), jak i dobrze funkcjonującą komunikacją PKS (przystanek jest bezpośrednio usytuowany przy Geostanowisku 1).

Godne uwagi turysty jest odsłonięcie skał węglanowych o dużych walorach edukacyjnych i naukowych. Polecam to miejsce zwłaszcza na szkolną wycieczkę. Łatwy i bezpieczny dostęp do ścian wapiennych umożliwi przeprowadzenie lekcji rozpoznawania skał i skamieniałości $\mathrm{w}$ terenie, a możliwość zorganizowania pikniku i spacer na wzgórze $\mathrm{z}$ 
ruinami zamkowymi bez wątpienia spodoba się nastolatkom. Uczniowie mogą porównać skały widoczne w Geostanowisku $1 \mathrm{z}$ materiałem budulcowym kaplicy i ruin zamku. Wycieczkę warto uzupełnić o krótką lekcję historii przeprowadzoną w okolicach wzgórza zamkowego oraz np. zorganizować podchody pt „Szukamy źródełka”.

Opisywana wieś dba o swój wizerunek i atrakcje turystyczne. W 2012 roku zostały przeprowadzone prace konserwatorskie zabezpieczające ruiny zamku, wykonano nowe schody prowadzące na szczyt wzgórza, postawiono tablice informacyjne przy Geostanowisku 1 oraz u stóp wzgórza (Stanowisko 2). Środki na ten cel pochodziły z budżetu Gminy Klucze, z funduszy unijnych oraz od darczyńców.

Myślę, iż gmina powinna jeszcze zadbać o czystość i ochronę opisywanego tu stanowiska skał węglanowych. W Bydlinie bywam regularnie od kilku lat, i obserwuję z niepokojem rosnące nielegalne wysypisko śmieci. Może ustanowienie tego miejsca stanowiskiem dokumentacyjnym (w myśl Ustawy o Ochronie Przyrody z dnia 16 kwietnia 2004 roku), ustawienie tablic zakazujących wysypywanie śmieci i oczywiście kary finansowe dla osób ewidentnie łamiących ten zakaz pomogą uporać się z problemem.

\section{SŁOWNIK TERMINÓW GEOLOGICZNYCH (częściowo wg Mizerski i Sylwestrzak, 2002)}

bioherma - węglanowa budowla biogeniczna o soczewkowatej formie, zbudowana ze szczątków organizmów osiadłych (np. jak w Bydlinie z gąbek), żyjących w mule

budowla węglanowa - masy osadów węglanowych utworzone z nagromadzenia na dnie organizmów bentonicznych; w postaci soczewy (= bioherma) lub ciała o większej rozciągłości lateralnej, warstwowanego (= biostroma)

czert - osadowa skała krzemionkowa, czyli zawierająca $\mathrm{SiO}_{2}$. Graniczy w sposób nieostry od skały węglanowej ją otaczającej (w Bydlinie barwy białej)

galena - minerał, siarczek ołowiu $\mathrm{PbS}$; najważniejsza ruda ołowiu (86,6 \% Pb) i główne źródło srebra

geostanowisko - są to wszelkie obiekty i zjawiska o szczególnych walorach geoturystycznych, zwykle objęte ochroną prawną. Według restrykcyjnej definicji geostanowisko powinno być rezultatem tylko i wyłącznie procesów naturalnych, natomiast w rozumieniu mniej restrykcyjnym - geostanowisko może również powstać przy współudziale człowieka (Żaba i Gaidzik, 2010)

marmur - inaczej wapień krystaliczny; węglanowa skała metamorficzna, powstała w warunkach wysokiego ciśnienia i temperatury. Od starożytności cenne tworzywo w architekturze i rzeźbie

monoklina - zespół warstw skalnych nachylonych pod jednym kątem i w jednym kierunku, leżących na sobie w następstwie normalnym (czyli młodsze skały na starszych)

Oksford - najstarsze piętro (wiek) górnej (późnej) jury, którego skały powstawały około 154-146 mln lat temu; nazwa pochodzi od miejscowości w Anglii

podstawa falowania - głębokość do jakiej sięga ruch falowy wody wywołany przez falowanie w trakcie normalnego stanu morza, przerabiający osad spoczywający na dnie

sedymentacja - proces osadzania się produktów erozji i wietrzenia skał wcześniej istniejących, szczątków organicznych, zachodzący w warunkach lądowych lub morskich, pod wpływem różnych czynników; prowadzi do powstania osadów i skał osadowych

transzeja - element fortyfikacji obronnych i oblężniczych, w postaci odkrytego, wąskiego i dostatecznie głębokiego rowu, służący przemieszczaniu się żołnierzy i osłaniający ich przed ogniem wroga

zdarzenie katastroficzne (= sedymentacja katastroficzna) - krótkotrwałe, incydentalne zdarzenie związane z okresem znacznego i nagłego wzrostu energii środowiska (w Bydlinie związane z aktywnością tektoniczną i obecnością uskoku) 


\section{References}

[1] Dżułyński Stanisław, Rocznik Polskiego Towarzystwa Geologicznego 21 (1952) 125-180.

[2] Kajzer Leszek, Salm Jan, Kołodziejski Stanisław, Wydawnictwo Arkady (2001) 591 pp.

[3] Kiryk Feliks, Kołodziejczyk Ryszard, PWN, Warszawa-Kraków, 1978, pp. 576.

[4] Marzec Leszek, Mazurek Kazimierz, Suchecki Tomasz. Wydawnictwo PTTK „Kraj” Warszawa, 1986, pp. 200.

[5] Mizerski Włodzimierz, Sylwestrzak Hubert. Wydawnictwa Naukowe, PWN, 2002, pp. 243.

[6] Różycki Stefan Zbigniew, Przegląd Geologiczny 8 (1960) 408.

[7] Stróżecki Andrzej, Zarząd Zespołu Jurajskich Parków Krajobrazowych woj. katowickiego, Dabrowa Górnicza, 1995, pp. 56.

[8] Sypek Robert. Agencja Wydawnicza CB, 2001, pp. 143.

[9] Vierek Aleksandra, Przeglad Geologiczny 4 (1997) 428-430.

[10] Vierek Aleksandra, Lewandowski Józef, Malik Kazimiera, Salamon Tomasz, Wydawnictwa Uniwersytetu Ślaskiego, Katowice, 2011, pp. 106.

[11] Zinkow Julian, Sport i Turystyka. Wydanie III rozszerzone, Warszawa, 1983, pp. 383.

[12] Żaba Jerzy, Gaidzik Krzysztof, Biuletyn Naukowy Wrocławskiej Wyższej Szkoły Informatyki Stosowanej Turystyka i Rekreacja, 1 (2010) 6-13.

[13] Żelaźniewicz Andrzej, Aleksandrowski Paweł, Buła Zbigniew, Karnkowski Paweł Henryk i wsp., Komitet Nauk Geologicznych, Wroctaw, 2011, pp. 60. 